\title{
Response of Chrysanthemum (Chrysanthemum morifolium) to Fresh and Exhausted Mushroom Compost Substrates in Greenhouse Conditions
}

\author{
Nuray ÇİÇEK ATIKMEN ${ }^{1 *}$, Cihat KÜTÜK²), Gülay KARAHAN ${ }^{3)}$ \\ ${ }^{1)}$ Cankırı Karatekin University, Faculty of Forestry, Landscape Architecture, Department of Plant Mate- \\ rial and Cultivation, Cankırı, Turkey. \\ ${ }^{2)}$ Ankara University, Agricultural Faculty, Department Soil Science and Plant Nutrition, Ankara \\ ${ }^{3}$ Cankırı Karatekin University, Faculty of Forestry, Department of Soil Science and Ecology. Cankırı, \\ Turkey. \\ ${ }^{*}$ Corresponding author, e-mail: ciceknuray@karatekin.edu.tr
}

Bulletin UASVM Horticulture 71(2) / 2014

Print ISSN 1843-5254, Electronic ISSN 1843-5394

DOI:10.15835/buasvmcn-hort:10353

\begin{abstract}
Chrysanthemum is one of the most popular perennial ornamental plants in Turkey. In this greenhouse study, fresh (unweathered) and exhausted (weathered 2 years) mushroom compost have been used as organic substrates for cultivation of Chrysanthemum (Chrysanthemum morifolium 'Vista'). In this context, 13 different mixtures composed of mushroom compost; fresh or exhausted, peat (organic soil) and perlite were tested. Each mixture was tested five replicates in completely randomized designed and the effects of mentioned 13 mixtures on nutrients determined in the end of the trial were compared. All mixtures were tested for some physical and chemical characteristics (nitrogen, phosphorus, potassium, calcium, magnesium, sodium, iron, zinc, manganese and copper). Overall results indicated that $12.5 \%$ fresh mushroom compost and $25 \%$ exhausted mushroom compost were the best ratios for cultivation of chrysanthemum.
\end{abstract}

Keywords: Crysanthemum, growth parameters, growth substrates, fresh mushroom compost, exhausted mushroom compost

\section{INTRODUCTION}

In the world and in Turkey; each year significant amount of waste is generated from agricultural activities as well as factories which processing various agricultural products. These mentioned wastes are mostly accumulated at huge amounts and sometimes covering large areas in the business field of the factories and even can prevent proper factory operation. In Turkey, there are various companies producing mushroom in different regions. Today, resulted from the growing consumer demands, increasing number of mushroom farms and their capacities have been producing 7000-10.000 ton of spent mushroom compost per month or year (Özgüven, 1998). Organic materials like horse manure, poultry manure, wheat-rye-paddy stems, shredded corn stem and corncobs, cotton seed pulp, syrup, bran are used for preparing compost and inorganic materials like nitrogen fertilizers, calcium carbonate, and calcium sulphate are also added to that compost (Erkel, 1993).

Large amounts of spent compost are generated after mushroom harvesting. Because of its high organic material content and rich mineral composition, spent mushroom compost has capacity for major positive contribution to the improvement of the physical properties of soils and plant nutrition. Furthermore some studies have indicated that it can be used as a growth substrates (Male, 1981; Wang et al., 1984; Robbins et al., 1986; Maher, 1991; Özgüven, 1998; Wuest, 1991; Chong etal., 1994; Kütük, 2000; Çiçek, 2004). Peat is the most preferred material as a growth substrate in the ornamental plant production. But the high cost of the peat is forcing the farmers 
to search for new and more economical and local solutions. The low cost of spent mushroom compost, and its availability in large quantities has made this product more attractive for farmers those of big producers of vegetables, fruits and ornamental plants.

Since, reasons of this are blossoming in autumn, remaining bloomy for a long time, existence of its different alternatives. Furthermore, it has facility of using inside, because small bloomy forms of chrysanthemum can be grown in pots.

In this study was evaluated the nutrient status of chrysanthemum plant cultivated in substrates containing fresh and exhausted mushroom compost.

\section{MATERIALS AND METHODS}

Fresh mushroom compost was gathered just after the end of the mushroom harvest while the exhausted mushroom compost was collected from the samples in the storage area piles waiting for 2 years. Samples were dried at room temperature till the moisture level decreased to app. $25 \%$ and then sterilized with $1.5 \%$ formaldehyde after sifting with $6.35 \mathrm{~mm}$ mesh. Sifted fresh and exhausted mushroom compost were volumetrically $(\mathrm{v} / \mathrm{v})$ mixed with peat and perlite at different proportions and used for preparing the growth substrates (Tab. 1). At greenhouse pot experiment, seedlings of Chrysanthemum morifolium 'Vista' were used.

Each Chrysanthemum seedling was planted into $1 \mathrm{~L}$ pots with drainage gaps. Plant nutrient solution which was recommended by Sannoveld and Straver (1992) was applied to chrysanthemum seedlings.

Bulk density, volumetric water and water buffering capacity of growth substrates were determined according to De Boodt et al. (1972), while aeration capacity and available water content were determined according to De Boodt and Verdonck (1973). Organic material was determined according to DIN 11542 (1978), reaction $(\mathrm{pH})$ and electrical conductivity (EC) were determined according to Gabriels and Verdonck (1992) and the last cation exchange capacity (CEC) were determined according to U.S. Salinity Lab. Staff (1954). Total nitrogen was determined according to Bremner (1982) while total phosphorus and potassium were calculated according to Kacar (1972). Water soluble ammonium, nitrate, phosphorus, potassium, calcium, magnesium, sodium, iron, cupper, manganese and zinc were determined according to Kirven (1986). All leaf samples harvested from chrysanthemum were prepared according to Kacar (1972) while total nitrogen was determined with Kjeldahl method and total phosphorus, potassium, calcium, magnesium, sodium, iron, zinc, manganese and copper were also determined according to Kacar (1972).

\section{RESULTS AND DISCUSSION}

Some physical and chemical analyses of the materials used as growth substrates were given

Tab. 1. Plant growth substrates ratios

\begin{tabular}{|c|c|c|}
\hline Substrates & Contents & Abbreviations \\
\hline 1 & $100 \%$ Peat (control) & $100 \% \mathrm{P}$ \\
\hline 2 & $12.5 \%$ Fresh MC $+87.5 \%$ Peat & $12.5 \% \mathrm{FMC}+87.5 \% \mathrm{P}$ \\
\hline 3 & $25 \%$ Fresh MC $+75 \%$ Peat & $25 \% \mathrm{FMC}+75 \% \mathrm{P}$ \\
\hline 4 & $50 \%$ Fresh MC + $50 \%$ Peat & $50 \% \mathrm{FMC}+50 \% \mathrm{P}$ \\
\hline 5 & $12.5 \%$ Fresh MC $+25 \%$ Perlite $+62.5 \%$ Peat & $12.5 \%$ FMC $+25 \%$ Perlite $+62.5 \% \mathrm{P}$ \\
\hline 6 & $25 \%$ Fresh MC $+25 \%$ Perlite $+50 \%$ Peat & $25 \%$ FMC $+25 \%$ Perlite $+50 \% \mathrm{P}$ \\
\hline 7 & $50 \%$ Fresh MC $+25 \%$ Perlite $+25 \%$ Peat & $50 \%$ FMC $+25 \%$ Perlite $+25 \%$ P \\
\hline 8 & $12.5 \%$ Exhausted MC + 87.5 \% Peat & $12.5 \% \mathrm{EMC}+87.5 \% \mathrm{P}$ \\
\hline 9 & $25 \%$ Exhausted MC + $75 \%$ Peat & $25 \% \mathrm{EMC}+75 \% \mathrm{P}$ \\
\hline 10 & $50 \%$ Exhausted MC $+50 \%$ Peat & $50 \% \mathrm{EMC}+50 \% \mathrm{P}$ \\
\hline 11 & $12.5 \%$ Exhausted MC+ $25 \%$ Perlite $+62.5 \%$ Peat & $12.5 \%$ EMC $+25 \%$ Perlite $+62.5 \% \mathrm{P}$ \\
\hline 12 & $25 \%$ Exhausted MC + $25 \%$ Perlite + $50 \%$ Peat & $25 \%$ EMC + $25 \%$ Perlite + $50 \%$ P \\
\hline 13 & $50 \%$ Exhausted MC $+25 \%$ Perlite $+25 \%$ Peat & $50 \%$ EMC $+25 \%$ Perlite $+25 \% P$ \\
\hline
\end{tabular}


in table 2 and table 3. Generally, bulk density of the materials used in the growth substrates is low. The peat has the lowest bulk density value. Bulk density of the exhausted mushroom compost is higher than the fresh mushroom compost. The bulk density of the exhausted mushroom compost was lower than the fresh compost due to its smaller particle diameter as a result of mineralization process in nature. Aeration capacity of the materials used in the growth substrates varies between $13.33 \%-27.62 \%$, available water content is between $21.07 \%-32.66 \%$ and the water buffering capacity changes between $5.42 \%-6.73$ $\%$. In order to support optimum growth of the plant aeration capacity of the substrates is expected to be between $20 \%$ - $25 \%$, available water content between
$20 \%-30 \%$, and the water buffering capacity between $5 \%$ - 7 \% (De Boodt and Verdonck, 1972).As expected, organic material in general have lower aeration capacity, therefore they have good water content levels and water buffering capacity. All materials had organic matter values varied between 45.50$92.50 \%$. Naturally, peat has higher organic matter content than all materials. Chemical and physical properties of organic materials vary depending on the degree of decomposition, material origin and environmental chemistry (Çaycl, 1989).

Effect of growth substrates for nitrogen, potassium and sodium contents of the plants were statistically non-significant but for the phosphorus, calcium, magnesium, iron, manganese, zinc and

Tab. 2. Some physical properties of materials used as growth substrates

\begin{tabular}{rcccc}
\hline & Properties & Peat & FMC & EMC \\
\hline Bulk Density, g/cm & 0.12 & 0.22 & 0.48 \\
& $\mathrm{pF} 0$ & 88.59 & 92.26 & 84.35 \\
& $\mathrm{pF} 1$ & 70.40 & 68.45 & 71.02 \\
$\mathrm{~m}$ & 37.73 & 44.49 & 49.95 \\
$\mathrm{H}=10 \mathrm{~cm}$ Aeration Capacity, \% & 32.31 & 38.81 & 33.22 \\
Available Water Content, \% & 18.19 & 27.62 & 13.33 \\
Water Buffering Capacity, \% & 32.66 & 23.96 & 21.07 \\
\hline
\end{tabular}

Tab. 3. Some chemical properties of materials used as growth substrates

\begin{tabular}{|c|c|c|c|c|}
\hline & Properties & Peat & FMC & EMC \\
\hline \multicolumn{2}{|c|}{ Organic matter, \% } & 92.50 & 65.65 & 45.50 \\
\hline \multicolumn{2}{|c|}{ CEC, me/100g } & 135.06 & 47.14 & 52.49 \\
\hline \multicolumn{2}{|c|}{ Total N, \% } & 0.88 & 2.51 & 2.31 \\
\hline \multirow{13}{*}{$\begin{array}{l}\frac{0}{0} \\
\vdots \\
0 \\
0 \\
\frac{1}{3} \\
\frac{\omega}{\pi} \\
3\end{array}$} & NH4-N, ppm & 0.73 & 78.07 & 12.22 \\
\hline & $\mathrm{NA}_{3}-\mathrm{N}, \mathrm{ppm}$ & 5.75 & 332.45 & 54.12 \\
\hline & P, ppm & 5.49 & 4.36 & 4.36 \\
\hline & $\mathrm{K}, \mathrm{ppm}$ & 51.00 & 7322.00 & 102.00 \\
\hline & $\mathrm{Ca}$, ppm & 178.00 & 1119.00 & 754.00 \\
\hline & $\mathrm{Mg}, \mathrm{ppm}$ & 56.00 & 892.00 & 450.00 \\
\hline & $\mathrm{Na}, \mathrm{ppm}$ & 18.00 & 32.00 & 26.00 \\
\hline & $\mathrm{Fe}, \mathrm{ppm}$ & 0.07 & 3.49 & 1.57 \\
\hline & Zn, ppm & 1.30 & 3.84 & 2.04 \\
\hline & $\mathrm{Mn}, \mathrm{ppm}$ & 0.46 & 5.76 & 1.57 \\
\hline & $\mathrm{Cu}, \mathrm{ppm}$ & 0.17 & 2.28 & 2.85 \\
\hline & $\mathrm{pH}$ & 6.00 & 6.40 & 7.08 \\
\hline & $\mathrm{EC}, \mathrm{dS} / \mathrm{m}$ & 0.50 & 9.52 & 5.69 \\
\hline
\end{tabular}


copper content were found statistically significant (Tab. 4).

Growth substrates had important effects on the $\mathrm{P}$ content of the plants and highest $\mathrm{P}$ content was calculated as $1.09 \%$ in $25 \% \mathrm{EMC}+$ perlite + $50 \%$ peat substrate, while the lowest was in $50 \%$ FMC $+50 \%$ peat substrate with only $0.66 \%$ (Tab. 4). P content of the plants were found at levels of between $0.23 \%-0.70 \%$ which was accepted as sufficient by Jones et al. (1991) or a little over these values. However the plants utilized $\mathrm{P}$ at different levels and gained different $\mathrm{P}$ rate in their structures. This situation could be caused by different physical and chemical properties (Tab. 2 and 3) of the materials used for preparing the growth substrates. In the beginning of the experiment, especially the specially mixed growth substrates indicated different $\mathrm{pH}$ and $\mathrm{EC}$ values (Tab. 3) which could cause the plants to utilize $P$ at different levels. Kütük (2000) explained the differentiation of the nutrients in the codiaeum plants which had been grown in the substrates prepared with spent mushroom compost and spent tea compost by having different physicalchemical properties and the antagonisticsynergistics interactions between the nutrients.

Kütük et al. (1998) was indicated low aeration capacity, high $\mathrm{pH}$ and some organic toxic compounds could affect uptake of plant nutrient. In another study performed by Chong et al. (1991) resulted increasing rate of the spent mushroom compost in a substrate also increased the N, P and $\mathrm{K}$ quantity in the plant but this trend is not same for all the plants. Generally a limit value is not stated for $\mathrm{Na}$ content for the ornamental plants. However, Na content of the plants could be mostly vary between $0.004 \%-2.00 \%$ (Bergman, 1992).

The effect of the different growing substrates over the Ca content of the chrysanthemum plant were different and the highest calcium content was $2.57 \%$ in the $50 \% \mathrm{EMC}+50 \%$ peat and also $12.5 \%$ EMC $+25 \%$ perlite $+62.5 \%$ peat mixtures while the lowest was in the $100 \%$ peat substrates with a rate of $1.81 \%$ (Table 4). It was observed that the Ca content was higher in the plants grown in the fresh or exhausted mushroom content substrates than the plants grown in the control substrate. This could be caused by the properties of fresh or exhausted mushroom compost while adding Ca containing materials like lime, dolomite or gypsum in the mushroom compost in the pretreatment stage. Guo et al. (2001) stated there were high levels of $\mathrm{Ca}$ in the spent mushroom compost. Chong et al. (1991) determined that the Ca level in a plant increased depending upon the spent mushroom compost applications. Jones et al.

Tab. 4. The effect of growth substrates over the nutrients of chrysanthemum plant

\begin{tabular}{lccccc}
\hline \multicolumn{1}{c}{ Growth substrates } & $\begin{array}{c}\text { Total N } \\
\%\end{array}$ & $\begin{array}{r}\text { Total P } \\
\%\end{array}$ & $\begin{array}{c}\text { Total K } \\
\%\end{array}$ & $\begin{array}{c}\text { Total Na } \\
\text { ppm }\end{array}$ & $\begin{array}{c}\text { Total Ca } \\
\%\end{array}$ \\
\hline $100 \% \mathrm{P}$ & 4.04 n.s. & $1.07 \mathrm{~A}$ & $6.36^{\text {n.s. }}$ & 695 n.s. & $1.81 \mathrm{E}$ \\
$12.5 \% \mathrm{FMC}+87.5 \% \mathrm{P}$ & 3.90 & $0.79 \mathrm{CD}$ & 7.14 & 513 & $2.01 \mathrm{CDE}$ \\
$25 \% \mathrm{FMC}+75 \% \mathrm{P}$ & 3.84 & $0.87 \mathrm{BC}$ & 6.81 & 581 & $1.86 \mathrm{DE}$ \\
$50 \% \mathrm{FMC}+50 \% \mathrm{P}$ & 3.62 & $0.66 \mathrm{D}$ & 6.55 & 739 & $2.48 \mathrm{AB}$ \\
$12.5 \% \mathrm{FMC}+25 \%$ Perlite $+62.5 \% \mathrm{P}$ & 3.98 & $0.80 \mathrm{CD}$ & 6.68 & 705 & $2.07 \mathrm{BCD}$ \\
$25 \% \mathrm{FMC}+25 \%$ Perlite $+50 \% \mathrm{P}$ & 3.83 & $0.79 \mathrm{CD}$ & 7.27 & 607 & $2.31 \mathrm{ABC}$ \\
$50 \% \mathrm{FMC}+25 \%$ Perlite $+25 \% \mathrm{P}$ & 3.75 & $0.84 \mathrm{BCD}$ & 7.20 & 597 & $2.44 \mathrm{AB}$ \\
$12.5 \% \mathrm{EMC}+87.5 \% \mathrm{P}$ & 3.71 & $0.93 \mathrm{ABC}$ & 6.82 & 784 & $2.25 \mathrm{ABCD}$ \\
$25 \% \mathrm{EMC}+75 \% \mathrm{P}$ & 3.91 & $0.95 \mathrm{ABC}$ & 6.70 & 619 & $2.19 \mathrm{ABCDE}$ \\
$50 \% \mathrm{EMC}+50 \% \mathrm{P}$ & 3.81 & $0.93 \mathrm{ABC}$ & 6.83 & 526 & $2.57 \mathrm{~A}$ \\
$12.5 \% \mathrm{EMC}+25 \%$ Perlite $+62.5 \% \mathrm{P}$ & 3.80 & $1.07 \mathrm{~A}$ & 7.05 & 614 & $2.57 \mathrm{~A}$ \\
$25 \% \mathrm{EMC}+25 \%$ Perlite $+50 \% \mathrm{P}$ & 3.91 & $1.09 \mathrm{~A}$ & 6.75 & 599 & $2.26 \mathrm{ABCD}$ \\
$50 \% \mathrm{EMC}+25 \%$ Perlite $+25 \% \mathrm{P}$ & 3.84 & $1.00 \mathrm{~A}$ & 7.20 & 579 & $2.34 \mathrm{ABC}$ \\
\hline
\end{tabular}

ns: non-significant, ${ }^{*} \mathrm{p}<0.01$ 
(1991) states the Ca values for the chrysanthemum plants as $0.90 \%-1.01 \%$ "low", $1.20 \%-2.50 \%$ "sufficient" and $>2.50 \%$ as "high". According to this data, plants were nurtured with enough level Ca.

Effect of different growth substrates over chrysanthemum plants $\mathrm{Mg}$ content were differential and highest $\mathrm{Mg}$ content had a ratio of $1.01 \%$ in $50 \%$ EMC $+25 \%$ perlite $+25 \%$ peat substrate while the lowest $\mathrm{Mg}$ content was $0.84 \%$ in $25 \%$ FMC $+75 \%$ peat substrate (Tab. 5). In a research by Chong et al. (1991) resulted Mg content in the plant was increased with the proportion of the spent mushroom content in the substrate. Jones et al. (1991) stated that sufficient Mg level for the chrysanthemum plant was between $0.25 \%-1.00$ $\%$. In terms of these values, it is possible to say the Mg contents of the plants are enough.

Effects of the different growth substrates on the Fe content of the chrysanthemum plant was also different and highest Fe content was with a value of $701.86 \mathrm{ppm}$ in $50 \% \mathrm{EMC}+50 \%$ peat substrate while the lowest Fe content was in 50 $\%$ FMC $+50 \%$ peat substrate with 305.50 ppm (Tab. 5) At higher $\mathrm{pH}$ values, available of Fe was limited (Kacar and Katkat, 1998) or low aeration capacity of exhausted mushroom compost could be cause this. Kacar and Katkat (1998) stated that in poor aeration conditions reduction of Fe caused an increase in solubility. For chrysanthemum plant $50 \mathrm{ppm}-250 \mathrm{ppm}$ Fe was accepted as a sufficient level (Jones et al., 1991). According to the obtained values it was observed that Fe level is high in the plants.

Different growth substrates effected the $\mathrm{Cu}$ content of the chrysanthemum plant different and the highest $\mathrm{Cu}$ content was $17.20 \mathrm{ppm}$ in the plants grown in $100 \%$ peat substrate while the lowest $\mathrm{Cu}$ content was in $25 \% \mathrm{FMC}+25 \%$ perlite $+50 \%$ peat substrate (Tab. 5). Jones et al. (1991) stated limit values of $\mathrm{Cu}$ in the chrysanthemum plant if between 4-5 ppm is "insufficient", 6-30 ppm "sufficient" and if $>30 \mathrm{ppm}$ it is "over content". According to this data it was understood that the $\mathrm{Cu}$ content of the plants were at normal values. Hicklenton (2004) stated spent application increases the $\mathrm{Cu}$ content of the plants.

Statistically significant was recognized in the Mn content of the chrysanthemum plant and the highest Mn content was $136 \mathrm{ppm}$ in $50 \% \mathrm{FMC}+$ $50 \%$ peat substrate while the lowest Mn content was in the plants grown in the $25 \%$ EMC +25 $\%$ perlite $+50 \%$ peat substrate with $81 \mathrm{ppm}$. (Tab. 5). This could be caused of the properties of fresh and exhausted mushroom compost (Table 1 and 2). While the Mn content in the plants were at different levels, the plants grown in the fresh mushroom compost containing substrates had generally higher levels. In a research performed by Chong et al. (1991) with 8 different ornamental plants showed similar results which Mn level increased relatively to the rate of spent mushroom compost in the substrate. When compared with the limit values stated by Jones et al. (1991), Mn level was sufficient in the chrysanthemum plants with a value of between $50 \mathrm{ppm}-250 \mathrm{ppm}$.

Effect of the different growth substrates to the Zn content of the chrysanthemum plant were also different and the highest $\mathrm{Zn}$ content was in the 50 $\%$ FMC $+25 \%$ perlite $+25 \%$ peat substrate with a value of $224 \mathrm{ppm}$ and the lowest $\mathrm{Zn}$ content was determined with a value of $48.97 \mathrm{ppm}$ in the plants grown in the substrates consisted of $12.5 \%$ FMC + $25 \%$ perlite $+62.5 \%$ peat (Tab. 5 ). It was thought that this situation could be caused by the different $\mathrm{pH}$ and EC values of the substrates. $\mathrm{Zn}$ content of the plants was found between $20-250$ ppm ranges which could be accepted as a sufficient level by Jones et al. (1991). However the plants used the Zn at different levels and gained different Zn quantity to their structures.

\section{CONCLUSION}

When the plant nutrients of the chrysanthemum was analyzed, plants' applications were not affected at important levels from the $\mathrm{N}, \mathrm{K}$ and $\mathrm{Na}$ contents while they were effected from the contents of $\mathrm{P}, \mathrm{Ca}, \mathrm{Mg}, \mathrm{Fe}, \mathrm{Mn}$ and $\mathrm{Zn}$. When compared with the plants grown in control substrate; P was found at similar levels in the plants which grown in substrates consisting of exhausted mushroom compost, but on the other hand, $\mathrm{P}$ level was decreasing in the plants grown in the substrates containing high fresh mushroom compost. So when mushroom compost is used as a growth substrate, $\mathrm{P}$ should be aware of. On the other hand, if fresh or exhausted mushroom compost is used in the substrates which chrysanthemum plant was grown; the $\mathrm{Ca}$ and $\mathrm{Mg}$ level was found higher than the control substrate but it is an important indication that this does not cause any problems. $\mathrm{Cu}, \mathrm{Mn}$ and $\mathrm{Zn}$ content 
Tab. 5. The effect of growth substrates over the nutrients of chrysanthemum plant

\begin{tabular}{lccrcc}
\hline \multicolumn{1}{c}{ Growth substrates } & $\begin{array}{c}\text { Total Mg } \\
\%\end{array}$ & $\begin{array}{c}\text { Total Fe } \\
\mathrm{ppm}\end{array}$ & $\begin{array}{c}\text { Total Mn } \\
\mathrm{ppm}\end{array}$ & $\begin{array}{c}\text { Total Zn } \\
\mathrm{ppm}\end{array}$ & $\begin{array}{c}\text { Total Cu } \\
\text { ppm }\end{array}$ \\
\hline $100 \% \mathrm{P}$ & $1.00 \mathrm{~A}$ & $701 \mathrm{~A}$ & $96 \mathrm{BC}$ & $144 \mathrm{BC}$ & $17 \mathrm{~A}$ \\
$12.5 \% \mathrm{FMC}+87.5 \% \mathrm{P}$ & $0.86 \mathrm{CD}$ & $405 \mathrm{CD}$ & $88 \mathrm{BC}$ & $166 \mathrm{~B}$ & $14 \mathrm{BC}$ \\
$25 \% \mathrm{FMC}+75 \% \mathrm{P}$ & $0.84 \mathrm{D}$ & $354 \mathrm{D}$ & $103 \mathrm{BC}$ & $100 \mathrm{C}$ & $15 \mathrm{ABC}$ \\
$50 \% \mathrm{FMC}+50 \% \mathrm{P}$ & $0.94 \mathrm{ABC}$ & $306 \mathrm{D}$ & $136 \mathrm{~A}$ & $49 \mathrm{D}$ & $14 \mathrm{C}$ \\
$12.5 \% \mathrm{FMC}+25 \%$ Perlite + 62.5 \% P & $0.90 \mathrm{BCD}$ & $463 \mathrm{BCD}$ & $90 \mathrm{BC}$ & $48 \mathrm{D}$ & $15 \mathrm{ABC}$ \\
$25 \% \mathrm{FMC}+25 \%$ Perlite + 50 \% P & $0.92 \mathrm{ABCD}$ & $505 \mathrm{BCD}$ & $86.29 \mathrm{C}$ & $156 \mathrm{~B}$ & $14 \mathrm{C}$ \\
$50 \% \mathrm{FMC}+25 \%$ Perlite $+25 \% \mathrm{P}$ & $0.95 . \mathrm{ABC}$ & $464 \mathrm{BCD}$ & $118 \mathrm{AB}$ & $224 \mathrm{~A}$ & $16 \mathrm{ABC}$ \\
$12.5 \% \mathrm{EMC}+87.5 \% \mathrm{P}$ & $0.95 \mathrm{ABC}$ & $566 \mathrm{ABC}$ & $101 \mathrm{BC}$ & $175 \mathrm{~B}$ & $16 \mathrm{ABC}$ \\
$25 \% \mathrm{EMC}+75 \% \mathrm{P}$ & $0.92 \mathrm{ABCD}$ & $659 \mathrm{AB}$ & $92 \mathrm{BC}$ & $156 \mathrm{~B}$ & $16 \mathrm{ABC}$ \\
$50 \% \mathrm{EMC}+50 \% \mathrm{P}$ & $0.95 \mathrm{ABC}$ & $702 \mathrm{~A}$ & $81 \mathrm{C}$ & $161 \mathrm{~B}$ & $14 \mathrm{C}$ \\
$12.5 \% \mathrm{EMC}+25 \%$ Perlite $+62.5 \% \mathrm{P}$ & $0.98 \mathrm{AB}$ & $495 \mathrm{BCD}$ & $99 \mathrm{BC}$ & $160 \mathrm{~B}$ & $15 \mathrm{ABC}$ \\
$25 \% \mathrm{EMC}+25 \%$ Perlite $+50 \% \mathrm{P}$ & $0.97 \mathrm{AB}$ & $466 \mathrm{BCD}$ & $81 \mathrm{C}$ & $155 \mathrm{~B}$ & $16 \mathrm{ABC}$ \\
$50 \% \mathrm{EMC}+25 \%$ Perlite $+25 \% \mathrm{P}$ & $1.01 \mathrm{~A}$ & $474 \mathrm{BCD}$ & $93 \mathrm{BC}$ & $170 \mathrm{~B}$ & $17 \mathrm{AB}$ \\
\hline
\end{tabular}

ns: non-significant, ${ }^{*} \mathrm{p}<0.01$

of chrysanthemum plant which were grown in fresh or exhausted mushroom compost containing substrates were found in desired limits (Jones et al., 1991); while the content of Fe content is found higher than the stated values (50 ppm-250 ppm).

In this case, if mushroom compost is thought to be used as a growth substrate which is important for nutrient $\mathrm{Fe}$ on chrysanthemum plant, $\mathrm{pH}$ and aeration capacity values must be carefully detected. Probably, pH adjustments and keeping the perlite proportion used in the mixtures a little bit higher or selecting its fraction at better values can help solving this problem.

In this study, for making the applications simpler, fresh mushroom compost and exhausted mushroom compost were used in chrysanthemum plant's growth substrate without any pretreatment. When the results are examined, it is resulted that fresh mushroom compost should be used primarily at $12.5 \%$ and as a secondary alternative can be $25 \%$. And for the exhausted mushroom compost; it can be used at a proportion of $25 \%$ in the first stage while can be used $50 \%$ as a secondary alternative.

After the product of cultivated mushroom industry; mushroom compost can be an important organic material for growing ornamental plants which are not sensitive against saltiness like chrysanthemum.
Acknowledgements. This study was a part of Nuray Çiçek Atikmen's Master Thesis.

\section{REFERENCES}

1.Bremner SM (1982). Total nitrogen. In: Methods of soil analysis. Part 2. p.595-624.Madison, WI, ASA-SSA.

2. Chong C, Cline RA, Rinker DL (1994). Bark and peat amended spent mushroom compost for containerized culture of shrubs. Horticultural Science 29(7):781-784.

3. Chong C, Cline RA, Rinker DL, Allen OB (1991). Growth on mineral nutrient status of containerized woody species in media amended with spent mushroom compost. Jour. of Hort. Sciences 116(2): 242-247.

4. Çaycı G (1989). An investigation on determination of properties of organic soil materials in Turkey as plant growth medium. Faculty of Agriculture, University of Ankara. Doctorate Thesis.

5. Çiçek N (2004). Atık mantar kompostu ile hazırlanan değişik yetiştirme ortamlarının krizantem (Chrysanthemum morifolium)'in gelişim parametreleri ve besin maddesi içeriğine etkisi. Ankara Üniversitesi Fen Bilimleri Enstitüsü Toprak Anabilim Dalı, Yüksek Lisans Tezi, 145s.

6. De Boodt M, Verdonck O (1972). The physical properties of the substrates in horticulture. Acta Horticulture 26: 37-44.

7. De Boodt M, Verdonck O, Cappaert I (1973). Method for measuring the water relase curve of organic substrates. Proceeding Sympossium Artifical Substrates in Horticulture 2054-2062.

8. DIN 11542 (1978). Torf für Gartenbau und Landwirstschaft.

9. Erkel İ (1993). Kültür mantarı yetiștiriciliği. Tarımsal Araştırmaları Destekleme ve Geliştirme Vakfı (TAV) 145 s. Yalova. 
10. Gabriels R, Verdonck 0 (1992). Reference methods for analysis of compost. In: Composting and compost quality assurance criteria, 173-183.

11. Guo M, Chorover J, Rosario R, Fox RH (2001). Leachate chemistry of field-weathered spent mushroom substrate. Jour. of Environ. Qual. 30: 1699-1709.

12. Hicklenton PR (2004). Effectiveness and consistency, of MSW compost as a component in container growing media. http:// www.compost.org/ccc.MSWCompost.htm.

13. Jones JB, Wolf B, Mills HA (1991). Plant analysis handbook. Micro-Macro Publishing Inc. 213 p.

14. Kacar B (1972). Bitki ve Toprağın Kimyasal Analizleri. II. Bitki Analizleri, Ankara Üniversitesi Ziraat Fakültesi Basımevi, 155, Ankara, 646 p.

15. Kacar B, Katkat AV (1998). Bitki Besleme, Uludağ Üniversitesi Güçlendirme Vakfı Yayın No:127, Vipsaş Yayınları;3, Özsan Matbaası, Bursa, 595 p.

16. Kirven DM (1986). An industry vievpoint: Horticultural testing is your language confusing. HortScience 21: 215217.

17. Kütük C (2000). Çay atığı kompostu ve atık mantar kompostunun yetiştirme ortamı bileşeni olarak süs bitkisi yetiştiriciliğinde kullanılması. Mustafa Kemal Üniversitesi Ziraat Fakültesi Dergisi 5(1-2):75-86.

18. Kütük C, Topçuoğlu B, Çaycı G (1998). The effect of different growing substrates on growth of croton (Codiaeum variegatum 'Petra') plant. M. Şefik Yeşilsoy International Symposium on Arid Region Soil, 499-505.
19. Maher MJ (1991). Spent mushroom compost (SMC) as a nutrient source in peat-based potting substrates. Mushroom Science 12(1):645-650.

20. Male RT (1981). The use of spent mushroom compost in vegetable production. Mushroom Science 11(1):111-121.

21. Özgüven AI (1998). The opportunities of using mushroom compost waste in strawberry growing. Turkish Jour. of Agric. and Forestry 22:601-607.

22. Robbins SH, Righetti TL, Fallahi E, Dixon AR, Chaplain MH (1986). Influence of trenching soil amendments and mulching on the mineral content, growth, yield and quality of "Italian" prunes. Commun. of Soil Sci. and Plant Analysis,17:457-471.

23. Sonnoveld C, Straver N (1992). Nutrient solutions for vegetables and flowers grown in water or substrates. Voedingsoplossingen glastuinbouw, 45, The Netherlands.

24. U.S. Salinity Laboratory Staff (1954). Diagnosis and improvement of saline and alkali soils. USDA, Agricultural Handbook 60, 160p.

25. Wang HS, Lohr VI, Coffey DL (1984). Spent mushroom compost as a soil amendment for vegetables. Jour. of Amer. Soc. for Horticulture Science 109:698-702.

26. Wuest PJ 1991. Development of procedure for using and storing spent mushroom compost to reduce the risk of lowering water quality. Pennsylvania Dept. Agr. Final Res. Proj. Report. University Park. 